Article

\title{
Silver Nanoparticles Functionalized with Sodium Mercaptoethane Sulfonate to Remove Copper from Water by the Formation of a Micellar Phase
}

\author{
Yesica Vicente-Martínez ${ }^{1}$ (D), Manuel Caravaca Garratón ${ }^{1, *(\mathbb{D})}$, María del Carmen García-Onsurbe ${ }^{2}$ \\ and Antonio Soto-Meca ${ }^{1}$ \\ 1 Department of Science, University Centre of Defence at the Spanish Air Force Academy, \\ Ministry of Defence-Technical University of Cartagena, C/Coronel López Peña s/n, 30720 Murcia, Spain; \\ yesica.vicente@cud.upct.es (Y.V.-M.); antonio.soto@cud.upct.es (A.S.-M.) \\ 2 Campus Alfonso XIII, Technical University of Cartagena, 30203 Cartagena, Spain; \\ mariadelcarmen.garcia2@edu.upct.es (M.d.C.G.-O.) \\ * Correspondence: manuel.caravaca@cud.upct.es
}

check for updates

Citation: Vicente-Martínez, Y.;

Caravaca Garratón, M.

García-Onsurbe, M.d.C.; Soto-Meca,

A. Silver Nanoparticles

Functionalized with Sodium

Mercaptoethane Sulfonate to Remove Copper from Water by the Formation of a Micellar Phase. Separations 2021, 8, 108. https://doi.org/10.3390/ separations 8080108

Academic Editor: Beatriz Albero

Received: 30 June 2021

Accepted: 26 July 2021

Published: 29 July 2021

Publisher's Note: MDPI stays neutral with regard to jurisdictional claims in published maps and institutional affiliations.

Copyright: (c) 2021 by the authors. Licensee MDPI, Basel, Switzerland. This article is an open access article distributed under the terms and conditions of the Creative Commons Attribution (CC BY) license (https:// creativecommons.org/licenses/by/ $4.0 /)$.

\begin{abstract}
This work presents a novel procedure for the removal of $\mathrm{Cu}^{2+}$ from water, an essential element in human nutrition considered toxic in high concentrations, based on a microextraction technique involving the formation of a micellar phase. To achieve the total elimination of copper from aqueous samples, a $\mathrm{Cu}^{2+}$-complexing reagent based on silver nanoparticles functionalized with sodium mercaptoethane sulfonate (AgNPs@MESNa) was used. The complex formed by $\mathrm{Cu}^{2+}$ and the reagent was extracted into a micellar microphase formed by Triton X-114, a harmless surfactant. Volumes of $200 \mu \mathrm{L}$ of the $10^{-4}$ mol L ${ }^{-1}$ suspension of AgNPs@MESNa and $100 \mu \mathrm{L}$ of a solution of Triton X-114 at $30 \% \mathrm{~m} / \mathrm{m}$ were employed to successfully remove $10 \mathrm{mg} \mathrm{L}^{-1}$ of Cu from $20 \mathrm{~mL}$ of water samples. The time and temperature needed to achieve $100 \%$ microextraction efficiency were $10 \mathrm{~min}$ and $40{ }^{\circ} \mathrm{C}$, respectively. The procedure is considered environmentally friendly due to the low volume of the extracting phase and the simple experimental conditions that achieve total removal of $\mathrm{Cu}^{2+}$ from water samples.
\end{abstract}

Keywords: copper removal; mercaptoethane sulfonate; micellar phase; microextraction; remediation; silver nanoparticles

\section{Introduction}

Copper is considered an essential element in human nutrition because it is involved in many enzymatic reactions, being one of the indispensable micronutrients. At least 30 copper-containing enzymes are known, whose functions include redox catalysis (cytochrome oxidase, nitrate reductase) or oxygen transportation (hemocyanin) [1,2]. High levels of copper are considered toxic, being of paramount importance for natural ecosystems [3]. The form that this metal presents (ionic, compound, or precipitated) depends on environmental factors, such as $\mathrm{pH}$, redox potential, soil and type of sediment, and water hardness and organic content, which could vary depending on the ecosystem $[3,4]$.

The levels of copper accessible in the environment greatly increase in areas with human activities that enhance its abundance [5], including smelting; mining; industrial activities; and the application of fertilizers, algaecides, and fungicides containing copper [6,7], which allow copper to pass through the soil. As a consequence of the contact of water with the earth's crust, copper salts can be found dissolved in surface water and in underground mantles due to industrial activity, usually in concentrations lower than $20 \mu \mathrm{g} \mathrm{L}{ }^{-1}$ [8]. However, at high concentrations, copper is toxic to organisms, its effect becoming stronger for plants and fish [9]. These higher concentrations can be found at points of water use as a result of corrosion of brass and copper pipes [10]. 
For these reasons, nowadays, the study and development of new techniques to eliminate copper from water is of capital importance. In the recent literature, numerous ways of eliminating $\mathrm{Cu}^{2+}$ from water and other matrices are found. Some of these techniques are based on oxidation processes [11-15], precipitation [16-20], and adsorption procedures that employ different materials as adsorbents [21-26].

Liquid-liquid extraction techniques are widely used to remove $\mathrm{Cu}^{2+}$ from water or soil due to their simplicity [27-30]. However, generally, these procedures require large volumes of solvents and sequential treatment, which significantly increases the cost and time employed to remove small amounts of copper. In recent years, interest in the use of nanoparticles to remove $\mathrm{Cu}^{2+}$ from water has grown [31-34], being most of the methods employed based on adsorption techniques which involve tedious procedures that do not achieve $100 \%$ adsorption efficiency.

In this work, we present a novel approach for the removal of $\mathrm{Cu}^{2+}$ from water samples combining the use of silver nanoparticles functionalized with sodium mercaptoethane sulfonate (AgNPs@MESNa) with a microextraction technique that uses a small volume of Triton X-114. This harmless surfactant forms a small micellar phase that allows the microextraction of $\mathrm{Cu}^{2+}$ by complexing with AgNPs@MESNa. After centrifuging, the microvolume is placed in the bottom of the flask, allowing its total separation. The experimental conditions to achieve the total elimination of $\mathrm{Cu}^{2+}$ from aqueous solutions are easy to achieve, being optimal at $\mathrm{pH}$ close to 3 , achieved by employing an appropriate amount of nitric acid, and preheating at $40{ }^{\circ} \mathrm{C}$ for $10 \mathrm{~min}$. The volumes of AgNPs@MESNa suspension and Triton $X-114$ solution necessary to eliminate $10 \mathrm{mg} \mathrm{L}^{-1}$ of $\mathrm{Cu}^{2+}$ from $20 \mathrm{~mL}$ of water are small $\left(200 \mu \mathrm{L}\right.$ of a $10^{-4} \mathrm{~mol} \mathrm{~L}^{-1}$ suspension of AgNPs@MESNa and $100 \mu \mathrm{L}$ of a solution of Triton X-114 at $30 \% \mathrm{~m} / \mathrm{m}$ ), which makes this procedure a cost-effective and environmentally friendly technique.

The method offers a novel alternative for the removal of $\mathrm{Cu}^{2+}$ from aqueous samples to adsorption techniques and classic extraction processes, which require large volumes of solvent and successive removals to totally eliminate $\mathrm{Cu}^{2+}$, leading to environmental issues and higher costs.

\section{Experimental Section}

\subsection{Materials and Instrumentation}

The solutions were prepared using deionized water purified with a Millipore system (Millipore, Bedford, MA, USA). The Cu(II) solution was prepared daily from $1 \mathrm{~g} \mathrm{~L}^{-1}$ of standards from Panreac (Barcelona, Spain) by adequate dilution. The surfactant Triton $X-$ 114 employed as the extractant medium was purchased from Fluka (Buchs SG, Switzerland) and used to prepare a $30 \% \mathrm{~m} / \mathrm{m}$ solution in ultrapure water and then kept in the refrigerator until use. The $10^{-4} \mathrm{~mol} \mathrm{~L}^{-1}$ solution of sodium 2-mercaptoethane sulfonate (MESNa; Sigma-Aldrich, Steinheim, Germany) was prepared before use in ultrapure water. Silver nitrate from Merck (Darmstadt, Germany) was used for the synthesis of silver nanoparticles. The reducing agent $\mathrm{NaBH}_{4}$ was obtained from Fluka and used in the solid state for the generation of silver nanoparticles.

A Perkin-Elmer Model 600 atomic absorption spectrometer equipped with Zeeman correction, a graphite furnace atomizer (ETAAS), and an AS-800 autosampler (Perkin-Elmer, Shelton, WA, USA) were used. The tubes equipped with the L'Vov platform were made of pyrolytic graphite and obtained from the same manufacturer. Argon was used as the inert gas, with a flow rate of $250 \mathrm{~mL} \mathrm{~min}^{-1}$ in all stages, except for the atomization stage, where the flow stopped. Copper and nickel hollow cathode lamps (Perkin-Elmer, Shelton, USA) operating at 15 and $25 \mathrm{~mA}$, respectively, were used.

A $50 \mathrm{~W}$ ultrasound bath (ATU, Valencia, Spain) with temperature control was used for the thermal treatment of the solutions and the degassing of the samples. The solutions were centrifuged in the Unicen 21 Centrifuge (Madrid, Spain) with a rotor and an adapter for $50 \mathrm{~mL}$ conical-bottom tubes up to $4000 \mathrm{rpm}$. 


\subsection{Preparation of Silver Nanoparticles Functionalized with Sodium 2-Mercaptoethanesulfonate} (AgNPs@MESNa)

Silver nanoparticles (AgNPs) were prepared by the reduction of Ag (I) [35]. For this purpose, $100 \mathrm{~mL}$ of $10^{-4} \mathrm{~mol} \mathrm{~L}^{-1}$ silver nitrate solution was placed in a flask. Under vigorous stirring, $0.012 \mathrm{~g}$ of solid $\mathrm{NaBH}_{4}$ was added. After $10 \mathrm{~min}$ of stirring, the mixture acquired a pale-yellow color. Afterward, $2 \mathrm{~mL}$ of a $10^{-4} \mathrm{~mol} \mathrm{~L}^{-1}$ aqueous solution of MESNa was added, stirring for $30 \mathrm{~min}$ until the suspension turned reddish. The prepared AgNPs@MESNa suspension was stable for several days at room temperature. After this process, the suspension of silver nanoparticles functionalized with MESNa was transferred to a topaz-colored bottle and stored in the refrigerator for better conservation.

\subsection{Proposed Procedure for the Removal of $\mathrm{Cu}^{2+}$ from Water}

Next, $20 \mathrm{~mL}$ of a water sample with a $\mathrm{Cu}^{2+}$ concentration of $10 \mathrm{mg} \mathrm{L}^{-1}$ was placed in a conical-bottom centrifuge tube. The $\mathrm{pH}$ was adjusted to 3 with the addition of $0.1 \mathrm{~mol} \mathrm{~L}^{-1}$ of commercial nitric acid at $70 \% w / w$ (approximately $200 \mu \mathrm{L}$ ) and preheated to $40{ }^{\circ} \mathrm{C}$. Then, $50 \mu \mathrm{L}$ of the AgNPs-MESNA solution and $100 \mu \mathrm{L}$ of the $30 \% \mathrm{~m} / \mathrm{m}$ aqueous Triton $\mathrm{X}-114$ solution were added. The mixture was stirred manually and heated at $40{ }^{\circ} \mathrm{C}$ for an additional $10 \mathrm{~min}$. Afterward, the dispersion was centrifuged at $3500 \mathrm{rpm}$ for $10 \mathrm{~min}$ and the extractant phase (Triton X-114) was separated, remaining at the bottom of the tube, and removed using a chromatographic syringe.

The $\mathrm{Cu}^{2+}$ content of the aqueous sample was determined by ETAAS before and after the microextraction process, showing that all the $\mathrm{Cu}^{2+}$ was removed in the micellar phase. In addition, to check that there were no traces of silver in the water sample, after removing the copper from the solution, the silver content was measured by ETAAS, showing no traces.

\section{Results and Discussion}

\subsection{Selection of the Functionalizing Reagent}

Modifying the surface of metallic nanoparticles with molecules containing functional groups is an appropriate way to alter their properties, making them suitable for use in various processes. A representative example is the functionalization of nanoparticles with biomolecules [36,37]. Nanoparticles exhibiting a protective monolayer surface can be obtained directly from precursors [38] by means of an exchange reaction with a suitable ligand [39] or by coupling with a suitable functional group [40]. Alkanethiols are the most widely studied monolayer ligands in the case of gold and silver nanoparticles because of the ability to attach to the surface through a metal-sulfur bond, leaving their carbon chains directed outward. Less studied is the use of bifunctional ligands that, on the one hand, associate with the surface of the nanoparticles and, on the other hand, act as complexing agents for metallic species. The coupling of metals on their surface expands the possibilities of their use in catalysis processes, sensors, and biomolecules [41]. In this work, MESNa was chosen as a bifunctional reagent since it contains an $\mathrm{S}$ atom to bind with the nanoparticle, while the sulfonate group would be responsible for the interaction with metal ions.

In a previous study on the use of MESNa-functionalized AgNPs for the determination of $\mathrm{Hg}^{2+}$ by surface-enhanced Raman scattering spectroscopy, it was manifested that the removal of mercury took place by means of its interaction with sulfur belonging to the thiol groups of MESNa [42]. Moreover, some other studies have revealed strong interactions between elements, such as copper, and sulfonate groups [43-46]. Therefore, in this work, the mechanism was driven by the same kind of interactions.

In the absence of AgNPs@MESNa, the extraction of $\mathrm{Cu}^{2+}$ in the condensed micellar phase was not observed. However, when MESNa was used at high concentrations $\left(10^{-4} \mathrm{~mol} \mathrm{~L}^{-1}\right)$, a low extraction of $\mathrm{Cu}^{2+}(22 \%)$ was obtained. This clearly indicates MESNa's ability to complex with metal ions. When a small concentration of AgNPs@MESNa was added instead of a high concentration of MESNa, a considerable increase in extraction was achieved. It is therefore evident that a strong interaction takes place 
between metal ions and functionalized silver nanoparticles, in addition to MESNa, thus reinforcing the role of silver nanoparticles.

\subsection{Effect of $\mathrm{pH}$ on $\mathrm{Cu}^{2+}$ Removal}

The $\mathrm{pH}$ of the medium had a strong effect on the extraction of the $\mathrm{Cu}^{2+}$ retained in the AgNPs@MESNa in the condensed micellar phase of Triton X-114, as shown in Figure 1. Error bars are smaller than the symbol size. The $\mathrm{pH}$ values were adjusted with the use of nitric acid, sodium hydroxide, and $0.001 \mathrm{~mol} \mathrm{~L}^{-1}$ of phosphate regulators. The maximum extraction efficiency was achieved at $\mathrm{pH}$ close to the zero-charge potential of AgNPs [47]. Although the potential of zero charge changes with the functionalizing species [48], a pH value lower than 3 is not advisable, because AgNPs can dissolve in the media. In view of the results obtained, the most suitable value was $\mathrm{pH}=3$, adjusted with the use of dilute nitric acid.

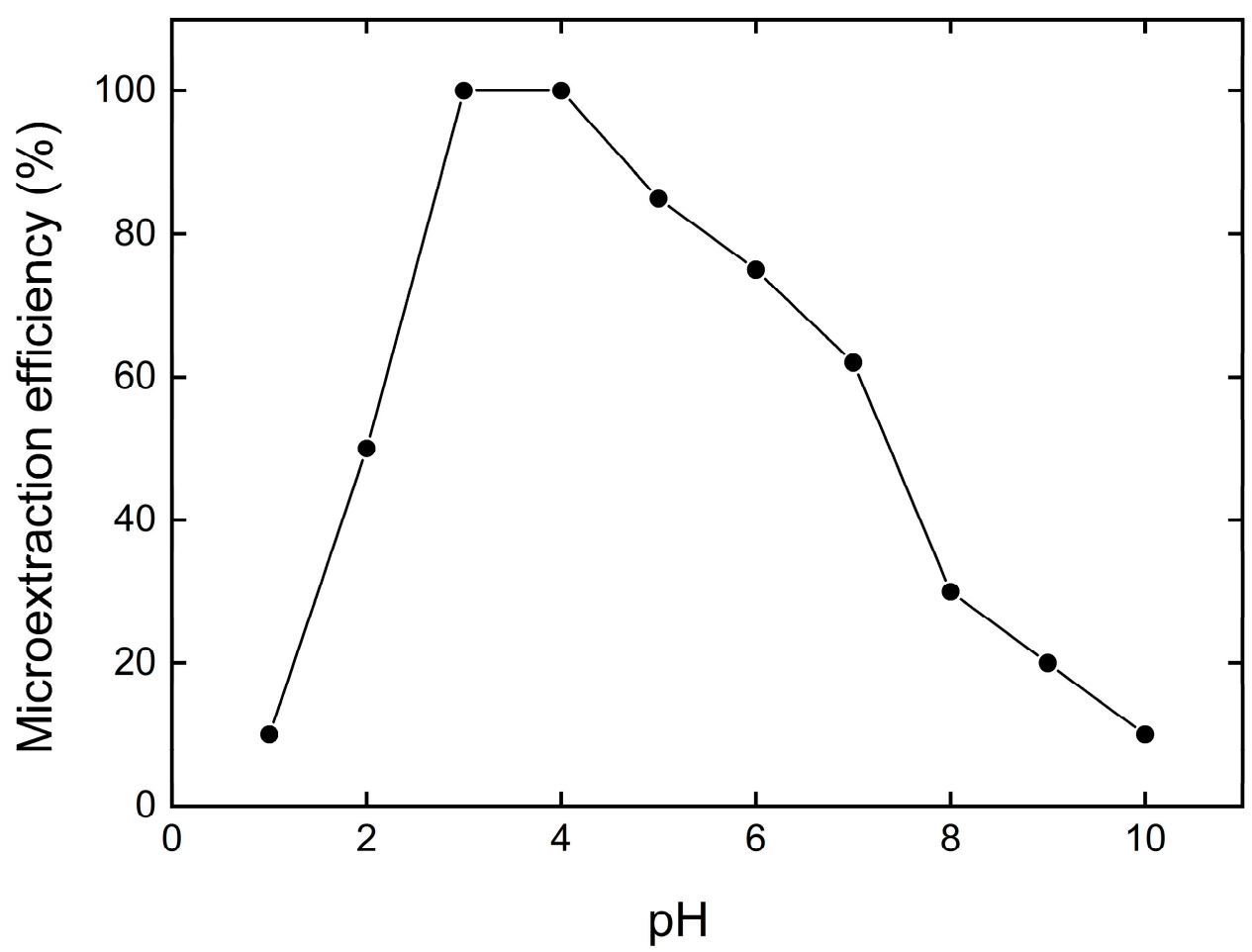

Figure 1. Dependence of microextraction efficiency on $\mathrm{pH}$ for the removal of $\mathrm{Cu}^{2+}$. The maximum efficiency was achieved at $\mathrm{pH}$ around 3. The straight line shows spline connectors.

\subsection{Effect of Triton $\mathrm{X}-114$ Concentration}

The concentration of Triton X-114 plays an important role as it must be high enough for the cloud to form in the solution $\left(3 \times 10^{-4} \mathrm{~mol} \mathrm{~L}^{-1}\right)$ [49], characterized by a cloudy appearance or scattering, while removing $100 \%$ of the $\mathrm{Cu}^{2+}$. In this work, we studied the effect of the concentration of Triton X-114 ranging from $0.02 \%$ to $0.5 \% v / v$, measuring $\mathrm{Cu}^{2+}$ by ETAAS both in the extract and in the aqueous phase. For an aqueous phase volume of $20 \mathrm{~mL}$, an increase in the microextraction efficiency with the concentration of Triton X-114 was observed, reaching the maximum for values between $0.05 \%$ and $0.1 \% v / v$. Higher concentrations unnecessarily increased the volume of the condensed phase, thus reducing the cost-effectiveness and making this technique less environmentally friendly. The addition of $100 \mu \mathrm{L}$ of Triton X-114 at $30 \% v / v$ to $20 \mathrm{~mL}$ of the aqueous phase was selected as the amount of surfactant that leads to the best results. In this way, approximately $38 \mu \mathrm{L}$ of the condensed phase was obtained. 


\subsection{Effect of Temperature on the Microextraction Efficiency of $\mathrm{Cu}^{2+}$}

The temperature at which the Triton X-114 cloud began to form was determined to be between 23 and $25^{\circ} \mathrm{C}$, although it changes according to the environmental conditions [50] since it depends on the interactions between the additives and the micelles. The effect of temperature and incubation time of the solution containing Triton X-114 was studied. Figure 2 shows the dependence of the microextraction efficiency of $\mathrm{Cu}^{2+}$ in the condensed phase on the temperature, between 25 and $70{ }^{\circ} \mathrm{C}$, after $15 \mathrm{~min}$ of a temperature bath. Error bars are smaller than the symbol size. Below $40^{\circ} \mathrm{C}$, the condensed phase volume obtained reduced, causing the $\mathrm{Cu}^{2+}$ not to be removed. From $40{ }^{\circ} \mathrm{C}$, this effect disappeared and all $\mathrm{Cu}^{2+}$ was eliminated up to $70^{\circ} \mathrm{C}$. The optimal temperature was selected as $40{ }^{\circ} \mathrm{C}$, since for higher values, more energy would need to be provided, thus reducing the cost-effectiveness of the process. Moreover, at $40^{\circ} \mathrm{C}$, the critical micellar concentration was reached, resulting in a reduction in the hydration of the hydrophilic group. This effect produces the cloud point of non-ionic surfactants and therefore favors micellization [8].

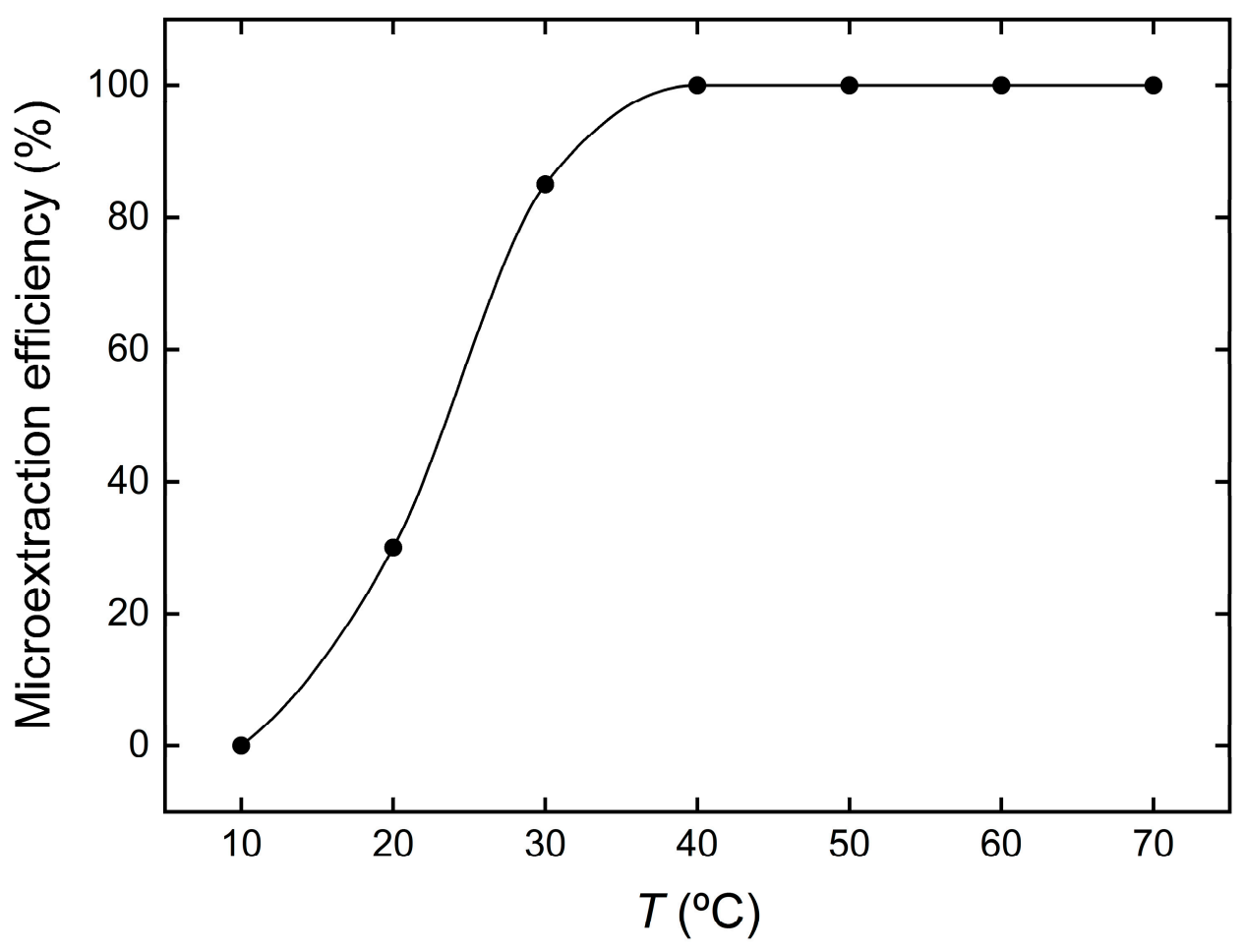

Figure 2. Dependence of $\mathrm{Cu}^{2+}$ removal efficiency on temperature. The optimal value was chosen as $40{ }^{\circ} \mathrm{C}$. The straight line shows Akima spline connectors.

\subsection{Contact Time Effect}

Regarding the time necessary for the extraction to take place, it was observed that from $15 \mathrm{~min}$ onward, the extraction of $\mathrm{Cu}^{2+}$ was complete, operating at $40^{\circ} \mathrm{C}$. However, if the sample containing the analytes and AgNPs@MESNa was preheated at $40{ }^{\circ} \mathrm{C}$ prior to the addition of Triton $\mathrm{X}-114$, the microextraction time reduced to $10 \mathrm{~min}$ and all $\mathrm{Cu}^{2+}$ was removed, as shown in Figure 3. Error bars are smaller than the symbol size. Therefore, it is recommended to incubate the sample for $10 \mathrm{~min}$ at $40{ }^{\circ} \mathrm{C}$ after the addition of Triton X-114 to accelerate the removal process. 


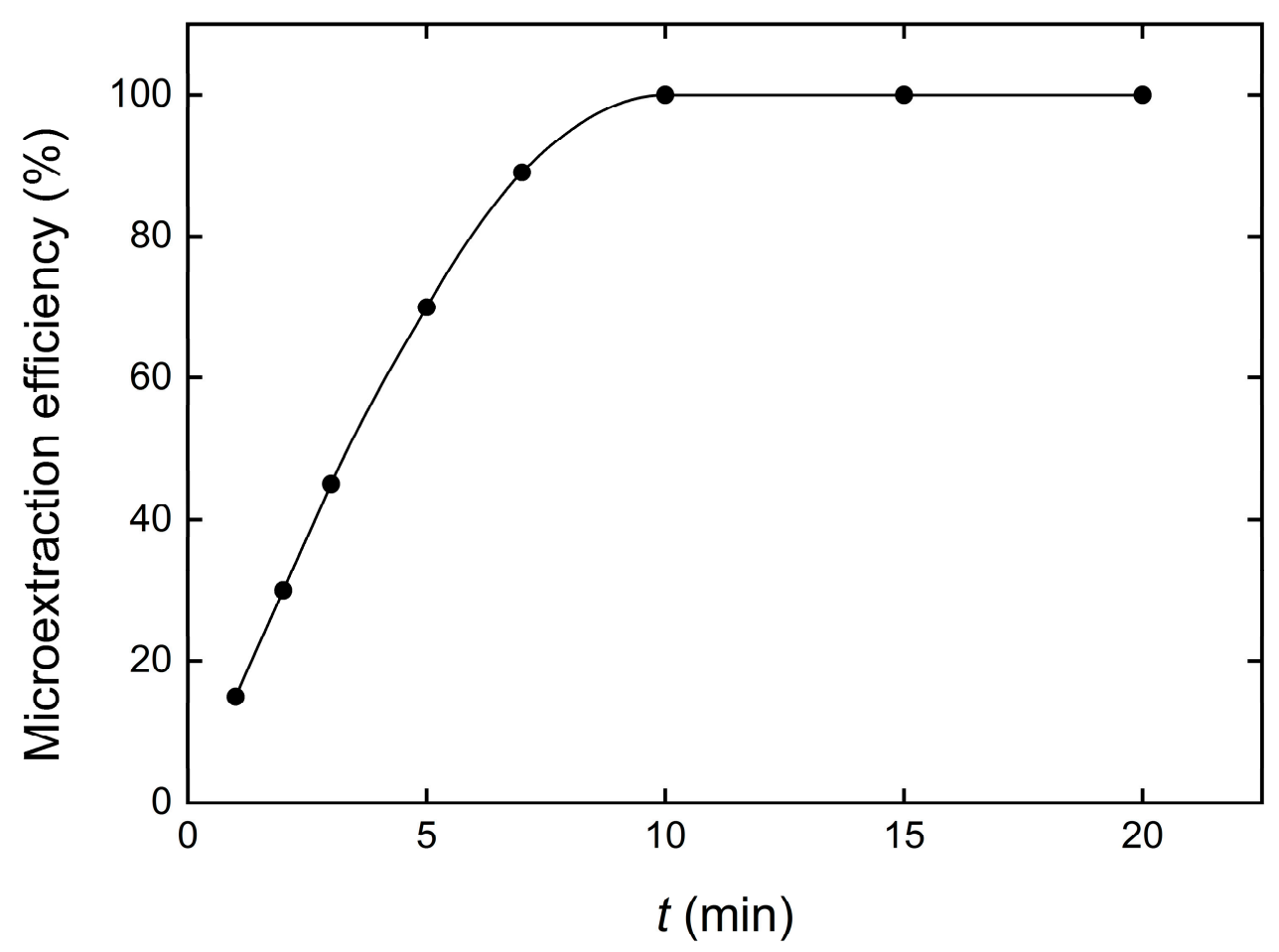

Figure 3. Dependence of microextraction efficiency on incubation time for the removal of $\mathrm{Cu}^{2+}$. The maximum efficiency was achieved in $10 \mathrm{~min}$ when the sample was preheated at $40^{\circ} \mathrm{C}$. The straight line shows Akima spline connectors.

\subsection{Effect of Other Ions Present in the Medium}

In the aquatic environment, there are numerous ions commonly present, such as $\mathrm{Pb}^{2+}$, $\mathrm{Cd}^{2+}, \mathrm{Cr}^{3+}, \mathrm{Cr}^{6+}, \mathrm{SO}_{4}{ }^{2-}, \mathrm{PO}_{4}{ }^{3-}, \mathrm{NO}_{3}{ }^{-}$, and $\mathrm{CO}_{3}{ }^{2-}$. To determine how they influence the proposed copper elimination process, the procedure has been applied in the presence of high concentrations of the indicated ions. The results reveal that for concentrations even 100 times higher than the concentration of copper, the removal of the latter is not affected.

In addition, to verify that the process could be suitable for real water samples, it was applied to four real water samples, two taken from the sea and two from the tap, all doped with a concentration of $\mathrm{Cu}^{2+}$ of $10 \mathrm{mg} \mathrm{L}^{-1}$. After applying the proposed procedure, all the copper was eliminated, proving this approach is applicable to real water samples.

\section{Conclusions}

This work introduced a novel procedure using silver nanoparticles functionalized with sodium 2-mercaptoethane sulfonate (AgNPs@MESNa) as an effective reagent for the retention and removal of the cationic form of $\mathrm{Cu}^{2+}$ from water samples. The nanoparticles were completely separated from the solution by their entrapment in the Triton X-114 micelles generated under appropriate experimental conditions. The high partition coefficient between both phases and a high-volume ratio of the aqueous-to-micellar phase allowed the removal of all $\mathrm{Cu}^{2+}$ present in water samples, proving this procedure as a novel alternative to traditional techniques for the elimination of high concentrations of $\mathrm{Cu}^{2+}$. This new procedure removes up to $10 \mathrm{mg} \mathrm{L}^{-1}$ of $\mathrm{Cu}^{2+}$ from $20 \mathrm{~mL}$ of water in $10 \mathrm{~min}$ without using high volumes of solvent and under mild experimental conditions. Additionally, the approach is fast, cost effective, and environmentally friendly.

Author Contributions: Conceptualization, Y.V.-M., M.C.G., M.d.C.G.-O. and A.S.-M.; Data curation, Y.V.-M., M.C.G., M.d.C.G.-O. and A.S.-M.; Formal analysis, Y.V.-M., M.C.G., M.d.C.G.-O. and A.S.-M.; Funding acquisition, Y.V.-M., M.C.G., M.d.C.G.-O. and A.S.-M.; Investigation, Y.V.-M., M.C.G., M.d.C.G.-O. and A.S.-M.; Methodology, Y.V.-M., M.C.G., M.d.C.G.-O. and A.S.-M.; Project administration, Y.V.-M., M.C.G. and A.S.-M.; Resources, Y.V.-M., M.C.G., M.d.C.G.-O. and A.S.-M.; Software, Y.V.-M., M.C.G., M.d.C.G.-O. and A.S.-M.; Supervision, Y.V.-M., M.C.G. and A.S.-M.; 
Validation, Y.V.-M., M.C.G., M.d.C.G.-O. and A.S.-M.; Visualization, Y.V.-M., M.C.G., M.d.C.G.-O. and A.S.-M.; Writing—original draft, Y.V.-M., M.C.G., M.d.C.G.-O. and A.S.-M.; Writing-review \& editing, Y.V.-M., M.C.G., M.d.C.G.-O. and A.S.-M. All authors have read and agreed to the published version of the manuscript.

Funding: This research received no external funding.

Institutional Review Board Statement: Not applicable.

Informed Consent Statement: Not applicable.

Acknowledgments: The authors want to thank the University Centre of Defence at the Spanish Air Force Academy, Spanish Ministry of Defence-Technical University of Cartagena, for financial support.

Conflicts of Interest: The authors declare no conflict of interest.

\section{References}

1. Beavington, F. Trace-Elements in Rainwater and Dry Deposition around a Smelting Complex. Environ. Pollut. 1977, 13, 127-131. [CrossRef]

2. Mohamed, M.E.; Frag, E.Y.; El Brawy, M.H. Rapid potentiometric sensor for determination of Cu(II) ions in food samples. Microchem. J. 2021, 164, 7. [CrossRef]

3. Zhu, F.K.; Wang, X.J.; Fan, W.X.; Qu, L.; Qiao, M.Y.; Yao, S.W. Assessment of potential health risk for arsenic and heavy metals in some herbal flowers and their infusions consumed in China. Environ. Monit. Assess. 2013, 185, 3909-3916. [CrossRef] [PubMed]

4. Karadjova, I.; Izgi, B.; Gucer, S. Fractionation and speciation of $\mathrm{Cu}, \mathrm{Zn}$ and $\mathrm{Fe}$ in wine samples by atomic absorption spectrometry. Spectrochim. Acta Part B At. Spectrosc. 2002, 57, 581-590. [CrossRef]

5. Ramlan; Basir-Cyio, M.; Napitupulu, M.; Inoue, T.; Anshary, A.; Mahfudz; Isrun; Rusydi, M.; Golar; Sulbadana; et al. Pollution and contamination level of $\mathrm{Cu}, \mathrm{Cd}$, and $\mathrm{Hg}$ heavy metals in soil and food crop. Int. J. Environ. Sci. Technol. 2021. [CrossRef]

6. Sinaei, M.; Zare, R.; Matin, M.T.; Ghasemzadeh, J. Marine Debris and Trace Metal (Cu, Cd, Pb, and Zn) Pollution in the Stranded Green Sea Turtles (Chelonia mydas). Arch. Environ. Contam. Toxicol. 2021, 80, 634-644. [CrossRef]

7. Armid, A.; Shinjo, R.; Takwir, A.; Ruslan, R.; Wijaya, A.R. Spatial Distribution and Pollution Assessment of Trace Elements Pb, $\mathrm{Cu}, \mathrm{Ni}, \mathrm{Fe}$ and As in the Surficial Water of Staring Bay, Indonesia. J. Braz. Chem. Soc. 2021, 32, 299-310. [CrossRef]

8. Lopez-Garcia, I.; Vicente-Martinez, Y.; Hernandez-Cordoba, M. Determination of very low amounts of free copper and nickel ions in beverages and water samples using cloud point extraction assisted by silver nanoparticles. Anal. Methods 2015, 7, $3786-3792$. [CrossRef]

9. Yan, C.Y.; Zhuang, T.; Bai, J.H.; Wen, X.J.; Lu, Q.Q.; Zhang, L. Assessment of As, Cd, Zn, Cu and Pb Pollution and Toxicity in River Wetland Sediments and Artificial Wetland Soils Affected by Urbanization in a Chinese Delta. Wetlands 2020, 40, 2799-2809. [CrossRef]

10. Kamnoet, P.; Aeungmaitrepirom, W.; Menger, R.F.; Henry, C.S. Highly selective simultaneous determination of Cu(ii), Co(ii), $\mathrm{Ni}(\mathrm{ii}), \mathrm{Hg}$ (ii), and $\mathrm{Mn}$ (ii) in water samples using microfluidic paper-based analytical devices. Analyst 2021, 146, 2229-2239. [CrossRef]

11. Nguyen, M.K.; Tran, V.S.; Pham, T.T.; Pham, H.G.; Hoang, B.L.; Nguyen, T.H.; Tran, T.H.; Ngo, H.H. Fenton/ozone-based oxidation and coagulation processes for removing metals $(\mathrm{Cu}, \mathrm{Ni})$-EDTA from plating wastewater. J. Water Process Eng. $2021,39$. [CrossRef]

12. Honarmandrad, Z.; Javid, N.; Malakootian, M. Efficiency of ozonation process with calcium peroxide in removing heavy metals $(\mathrm{Pb}, \mathrm{Cu}, \mathrm{Zn}, \mathrm{Ni}, \mathrm{Cd})$ from aqueous solutions. SN Appl. Sci. 2020, 2. [CrossRef]

13. Chang, L.P.; Cao, Y.J.; Peng, W.J.; Miao, Y.H.; Fan, G.X.; Li, C.; Huang, Y.K.; Song, X.Y. Enhancing the ion flotation removal of $\mathrm{Cu}(\mathrm{II})$ via regulating the oxidation degree of nano collector-graphene oxide. J. Clean. Prod. 2021, 295. [CrossRef]

14. Grudzien, K.; Nogas, W.; Szczepaniak, G.; Grela, K. Larger scale Stahl oxidation with instant Cu removal in convenient synthesis of chiral bidentate N-heterocyclic carbene precursor. Polyhedron 2021, 199. [CrossRef]

15. Wu, K.; Wang, M.; Li, A.Z.; Zhao, Z.X.; Liu, T.; Hao, X.D.; Yang, S.J.; Jin, P.K. The enhanced As(III) removal by Fe-Mn-Cu ternary oxide via synergistic oxidation: Performances and mechanisms. Chem. Eng. J. 2021, 406. [CrossRef]

16. Wu, L.Y.; Peng, B.; Li, Q.Z.; Wang, Q.W.; Yan, X.; Lin, Q.H.; Ji, C.L. Formation of high crystalline LDH sludge for removing Cu and Zn from wastewater by controlled double-jet precipitation. Environ. Sci. Pollut. Res. 2019, 26, 19665-19675. [CrossRef]

17. Liu, Y.; Wang, D.F.; Xue, M.M.; Song, R.Y.; Zhang, Y.; Qu, G.Z.; Wang, T.C. High-efficient decomplexation of Cu-EDTA and Cu removal by high-frequency non-thermal plasma oxidation/alkaline precipitation. Sep. Purif. Technol. 2021, 257. [CrossRef]

18. Guo, P.P.; Kong, L.H.; Hu, X.Y.; Peng, X.J.; Wang, X.L. Removal of Cl(-I) from strongly acidic wastewater containing Cu(II) by complexation-precipitation using thiourea: Efficiency enhancement by ascorbic acid. J. Hazard. Mater. 2021, 402. [CrossRef]

19. Xiong, B.W.; Zhang, T.T.; Zhao, Y.L.; Wen, T.; Zhang, Q.W.; Bao, S.X.; Song, S.X. Removal of Cu(II) from wastewater by using mechanochemically activated carbonate-based tailings through chemical precipitation. Environ. Sci. Pollut. Res. 2019, 26, 35198-35207. [CrossRef] 
20. Shan, C.; Xu, Z.; Zhang, X.L.; Xu, Y.; Gao, G.D.; Pan, B.C. Efficient removal of EDTA-complexed Cu(II) by a combined $\mathrm{Fe}(\mathrm{III}) / \mathrm{UV} /$ alkaline precipitation process: Performance and role of Fe(II). Chemosphere 2018, 193, 1235-1242. [CrossRef]

21. Pavithra, S.; Thandapani, G.; Sugashini, S.; Sudha, P.N.; Alkhamis, H.H.; Alrefaei, A.F.; Almutairi, M.H. Batch adsorption studies on surface tailored chitosan/orange peel hydrogel composite for the removal of $\mathrm{Cr}(\mathrm{VI})$ and $\mathrm{Cu}(\mathrm{II})$ ions from synthetic wastewater. Chemosphere 2021, 271. [CrossRef]

22. Luo, H.Y.; Liu, Y.; Lu, H.X.; Fang, Q.; Rong, H.W. Efficient Adsorption of Tetracycline from Aqueous Solutions by Modified Alginate Beads after the Removal of Cu(II) Ions. ACS Omega 2021, 6, 6240-6251. [CrossRef]

23. Zhang, X.; Shan, R.R.; Li, X.G.; Yan, L.G.; Ma, Z.M.; Jia, R.B.; Sun, S.H. Effective removal of Cu(II), Pb(II) and Cd(II) by sodium alginate intercalated MgAl-layered double hydroxide: Adsorption properties and mechanistic studies. Water Sci. Technol. 2021, 83, 975-984. [CrossRef]

24. Wang, L.; Luo, Z.J.; Chelme-Ayala, P.; Wei, J.; Zhou, X.T.; Min, Y.H.; El-Din, M.G.; Wu, Z.R. The removal of Cu(II)-EDTA chelates using green rust adsorption combined with ferrite formation process. J. Environ. Manag. 2021, 279. [CrossRef]

25. Abou-Zeid, R.E.; Ali, K.A.; Gawad, R.M.A.; Kamal, K.H.; Kamel, S.; Khiari, R. Removal of Cu(II), Pb(II), Mg(II), and Fe(II) by Adsorption onto Alginate/Nanocellulose Beads as Bio-Sorbent. J. Renew. Mater. 2021, 9, 601-613. [CrossRef]

26. Yang, L.W.; Peng, Y.Q.; Qian, C.F.; Xing, G.H.; He, J.J.; Zhao, C.L.; Lai, B. Enhanced adsorption/photocatalytic removal of Cu(II) from wastewater by a novel magnetic chitosan@ bismuth tungstate coated by silver (MCTS-Ag/ $\mathrm{Bi}_{2} \mathrm{WO}_{6}$ ) composite. Chemosphere 2021, 263. [CrossRef] [PubMed]

27. Bozejewicz, D.; Osmialowski, B.; Kaczorowska, M.A.; Witt, K. 2,6-Bis((benzoyl-R)amino)pyridine (R = H, 4-Me, and 4-NMe2) Derivatives for the Removal of $\mathrm{Cu}(\mathrm{II}), \mathrm{Ni}(\mathrm{II}), \mathrm{Co}(\mathrm{II})$, and $\mathrm{Zn}$ (II) Ions from Aqueous Solutions in Classic Solvent Extraction and a Membrane Extraction. Membranes 2021, 11, 233. [CrossRef] [PubMed]

28. Isosaari, P.; Marjavaara, P.; Lehmus, E. Sequential electrokinetic treatment and oxalic acid extraction for the removal of $\mathrm{Cu}, \mathrm{Cr}$ and As from wood. J. Hazard. Mater. 2010, 182, 869-876. [CrossRef] [PubMed]

29. Chague-Goff, C. Assessing the removal efficiency of $\mathrm{Zn}, \mathrm{Cu}, \mathrm{Fe}$ and $\mathrm{Pb}$ in a treatment wetland using selective sequential extraction: A case study. Water Air Soil Pollut. 2005, 160, 161-179. [CrossRef]

30. Lin, S.H.; Juang, R.S. Removal of free and chelated $\mathrm{Cu}(\mathrm{II})$ ions from water by a nondispersive solvent extraction process. Water Res. 2002, 36, 3611-3619. [CrossRef]

31. Wen, J.; Hu, X.H. Metal selectivity and effects of co-existing ions on the removal of Cd, Cu, Ni, and Cr by ZIF-8-EGCG nanoparticles. J. Colloid Interface Sci. 2021, 589, 578-586. [CrossRef]

32. Chang, L.L.; Pu, Y.P.; Jing, P.P.; Cui, Y.F.; Zhang, G.C.; Xu, S.; Cao, B.Y.; Guo, J.Y.; Chen, F.Y.; Qiao, C.F. Magnetic core-shell $\mathrm{MnFe}_{2} \mathrm{O}_{4} @ \mathrm{TiO}_{2}$ nanoparticles decorated on reduced graphene oxide as a novel adsorbent for the removal of ciprofloxacin and $\mathrm{Cu}$ (II) from water. Appl. Surf. Sci. 2021, 541. [CrossRef]

33. Hamdy, A. Experimental Study of the Relationship Between Dissolved Iron, Turbidity, and Removal of Cu(II) Ion From Aqueous Solutions Using Zero-Valent Iron Nanoparticles. Arab. J. Sci. Eng. 2021, 46, 5543-5565. [CrossRef]

34. Hosain, A.N.A.; El Nemr, A.; El Sikaily, A.; Mahmoud, M.E.; Amira, M.F. Surface modifications of nanochitosan coated magnetic nanoparticles and their applications in $\mathrm{Pb}(\mathrm{II}), \mathrm{Cu}(\mathrm{II})$ and $\mathrm{Cd}(\mathrm{II})$ removal. J. Environ. Chem. Eng. 2020, 8. [CrossRef]

35. Wu, X.Y.; Xu, Y.B.; Dong, Y.J.; Jiang, X.; Zhu, N.N. Colorimetric determination of hexavalent chromium with ascorbic acid capped silver nanoparticles. Anal. Methods 2013, 5, 560-565. [CrossRef]

36. Catarino, S.; Trancoso, I.M.; de Sousa, R.B.; Curvelo-Garcia, A.S. Grape must mineralization by high pressure microwave digestion for trace element analysis: Development of a procedure. Cienc. E Tec. Vitivinic. 2010, 25, 87-93.

37. Niemeyer, C.M. Nanoparticles, proteins, and nucleic acids: Biotechnology meets materials science. Angew. Chem. Int. Edit. 2001, 40, 4128-4158. [CrossRef]

38. Brust, M.; Walker, M.; Bethell, D.; Schiffrin, D.J.; Whyman, R. Synthesis of thiol-derivatized gold nanoparticles in a 2-phase liquid-liquid system. J. Chem. Soc. Chem. Commun. 1994, 801-802. [CrossRef]

39. Gittins, D.I.; Caruso, F. Tailoring the polyelectrolyte coating of metal nanoparticles. J. Phys. Chem. B 2001, $105,6846-6852$. [CrossRef]

40. Sommer, W.J.; Weck, M. Facile functionalization of gold nanoparticles via microwave-assisted 1,3 dipolar cycloaddition. Langmuir 2007, 23, 11991-11995. [CrossRef]

41. Wilton-Ely, J. The surface functionalisation of gold nanoparticles with metal complexes. Dalton Trans. 2008, 25-29. [CrossRef]

42. Chen, Y.; Wu, L.H.; Chen, Y.H.; Bi, N.; Zheng, X.; Qi, H.B.; Qin, M.H.; Liao, X.; Zhang, H.Q.; Tian, Y. Determination of mercury(II) by surface-enhanced Raman scattering spectroscopy based on thiol-functionalized silver nanoparticles. Microchim. Acta 2012, 177, 341-348. [CrossRef]

43. Rivas, B.L.; Schiappacasse, L.N.; Pereira, U.E.; Moreno-Villoslada, I. Interactions of polyelectrolytes bearing carboxylate and/or sulfonate groups with $\mathrm{Cu}(\mathrm{II})$ and $\mathrm{Ni}(\mathrm{II})$. Polymer 2004, 45, 1771-1775. [CrossRef]

44. Zhou, Y.; Zhao, H.; Li, C.; He, P.; Peng, W.B.; Yuan, L.F.; Zeng, L.X.; He, Y.J. Colorimetric detection of $\mathrm{Mn}^{2+}$ using silver nanoparticles cofunctionalized with 4-mercaptobenzoic acid and melamine as a probe. Talanta 2012, 97, 331-335. [CrossRef] [PubMed]

45. Ravindran, A.; Mani, V.; Chandrasekaran, N.; Mukherjee, A. Selective colorimetric sensing of cysteine in aqueous solutions using silver nanoparticles in the presence of $\mathrm{Cr}^{3+}$. Talanta 2011, 85, 533-540. [CrossRef] 
46. Zhou, Y.; Zhao, H.; He, Y.J.; Ding, N.; Cao, Q. Colorimetric detection of $\mathrm{Cu}^{2+}$ using 4-mercaptobenzoic acid modified silver nanoparticles. Colloid Surf. A-Physicochem. Eng. Asp. 2011, 391, 179-183. [CrossRef]

47. Liu, J.F.; Chao, J.B.; Liu, R.; Tan, Z.Q.; Yin, Y.G.; Wu, Y.; Jiang, G.B. Cloud Point Extraction as an Advantageous Preconcentration Approach for Analysis of Trace Silver Nanoparticles in Environmental Waters. Anal. Chem. 2009, 81, 6496-6502. [CrossRef]

48. Alvarez-Puebla, R.A.; Arceo, E.; Goulet, P.J.G.; Garrido, J.J.; Aroca, R.F. Role of nanoparticle surface charge in surface-enhanced Raman scattering. J. Phys. Chem. B 2005, 109, 3787-3792. [CrossRef] [PubMed]

49. Quina, F.H.; Hinze, W.L. Surfactant-mediated cloud point extractions: An environmentally benign alternative separation approach. Ind. Eng. Chem. Res. 1999, 38, 4150-4168. [CrossRef]

50. Meeravali, N.N.; Kumar, S.J. Determination of $\mathrm{Cd}, \mathrm{Pb}, \mathrm{Cu}, \mathrm{Ni}$ and $\mathrm{Mn}$ in effluents and natural waters by a novel salt induced mixed-micelle cloud point extraction using ETAAS. Anal. Methods 2012, 4, 2435-2440. [CrossRef] 